\title{
The GLOWA Volta Project: A framework for water resources decision-making and scientific capacity building in a transnational West African basin
}

\author{
Charles Rodgers · Nick van de Giesen • \\ Wolfram Laube · Paul L. G. Vlek · Eva Youkhana
}

Received: 20 April 2006

(C) Springer Science + Business Media B.V. 2006

\section{Introduction}

The Volta River Basin occupies over $400,000 \mathrm{~km}^{2}$ within the sub-humid to semi-arid West African savanna zone. The basin is shared by six riparian nations, among which Ghana (40\% of basin area) and Burkina Faso (43\%) are the most important in terms of population, water use and economic activity. Basin precipitation averages around 1,000 mm per year, with a steep south to north gradient, and less than $10 \%$ becomes usable as runoff due to high evaporation rates. Historically, rainfall is erratic and unreliable, a situation likely to be exacerbated as a consequence of global climate change. Basin inhabitants are largely rural and poor, with per capita incomes falling well below Sub-Saharan African standards, and only $37 \%$ (Burkina Faso) to $62 \%$ (Ghana) have access to improved sources of drinking water. Basin population is expanding by over $2.5 \%$ annually, effectively doubling every 28 years. Irrigation, the dominant consumptive use of water in the northern and central basin, competes directly with hydro-power generation in the south for available water resources, and the demand for water to serve these and other uses is projected to increase dramatically over the next two decades.

The GLOWA Volta Project (GVP), initiated in 2000 and funded by the German Government, is designed to provide a comprehensive, integrated analysis of the physical and socioeconomic determinants of the hydrologic cycle within the Volta Basin, with a specific focus on the impacts of global environmental change. GLOWA Volta is an interdisciplinary project involving climatologists, hydrologists, geographers and other physical scientists working in coordination with agricultural economists, sociologists and anthropologists. The overall

Integrated Assessment of Water Resources and Global Change: A North-South Analysis, 23-25 February 2005, Bonn

C. Rodgers · W. Laube · P. L. G. Vlek · E. Youkhana

Center for Development Research (ZEF), University of Bonn

N. van de Giesen

Department of Water Management, Delft University of Technology 
project objective is to design and to implement a scientifically sound Decision Support System (DSS) for the sustainable development of water resources in the Volta Basin under changing conditions.

The objective of this paper is to provide a description of the water resources situation, and of the community of stakeholders, within the Volta Basin. In particular, it proposes to examine the structure and activities of the GLOWA Volta Project, and the ongoing development of the DSS as a mechanism for improved stakeholder participation in the increasingly challenging task of basin water resources management. In the following sections, descriptions of the Volta Basin climate, physical and human geography and a brief synopsis of the status of water resources allocation are provided. In Section 3, important Volta water sector actors and institutions are identified. In Section 4, the GLOWA Volta Project is described, and significant activities and accomplishments are discussed. In the final section, the development of a prototype Decision Support System for the White Volta Basin in collaboration with the Ghanaian Water Resources Commission (WRC) is described. The GLOWA Volta Project approach will be shown to emphasize interdisciplinary research, participation in research networks, consultation with basin stakeholders at all levels of involvement, and investment in scientific capacity building.

\section{The Volta Basin}

\subsection{Physical features}

The Volta Basin is located in West Africa between $5^{\circ} .30 \mathrm{~N}-14^{\circ} 30 \mathrm{~N}$ and between $2^{\circ} .00$ $\mathrm{E}$ and $5^{\circ} .30 \mathrm{~W}$ (refer to Figure 1). The basin encompasses the majority of Ghana $(70 \%$ of land area) and Burkina Faso (63\%) and lesser proportions of Togo, Benin, Mali and Cote d'Ivoire, respectively (Table 1). It is in general a low relief basin, with elevations ranging from sea level to $920 \mathrm{~m}$, a mean elevation of $257 \mathrm{~m}$ and correspondingly low channel grades. The lower Volta is fed by three major tributaries. To the west, the Black Volta $\left(147,000 \mathrm{~km}^{2}\right)$ drains western Burkina Faso and small areas within Mali and Cote d'Ivoire; the White Volta $\left(106,000 \mathrm{~km}^{2}\right)$ drains much of northern and central Ghana and Burkina Faso, and to the east, the Oti $\left(72,000 \mathrm{~km}^{2}\right)$ drains the northwestern regions of Benin and Togo. The three tributaries join in Northern Ghana to form Volta Lake, impounded behind the Akosombo Dam. This dam and reservoir, completed in 1964, stores roughly 150 billion cubic meters (BCM) and has an installed hydropower generation capacity in excess of $900 \mathrm{MW}$ (Sutherland et al., 2004). With a surface area of $8,500 \mathrm{~km}^{2}$, Lake Volta is among the world's largest artificial lakes.

Table 1 Spatial distribution of Volta Basin between Riparian Nations

\begin{tabular}{lccc}
\hline Country & Country area of Volta Basin $\left(\mathrm{km}^{2}\right)$ & \% of Basin in country & $\%$ of country in Basin \\
\hline Burkina Faso & 178,000 & 42.65 & 63.0 \\
Ghana & 167,692 & 40.18 & 70.0 \\
Togo & 26,700 & 6.40 & 47.3 \\
Benin & 17,098 & 4.10 & 15.2 \\
Mali & 15,392 & 3.69 & 1.2 \\
Côte d'Ivoire & 12,500 & 2.99 & 3.9 \\
Total & $417,382^{*}$ & $100 \%$ & \\
\hline
\end{tabular}

Source. Andah and Gichuki, 2003

Springer 


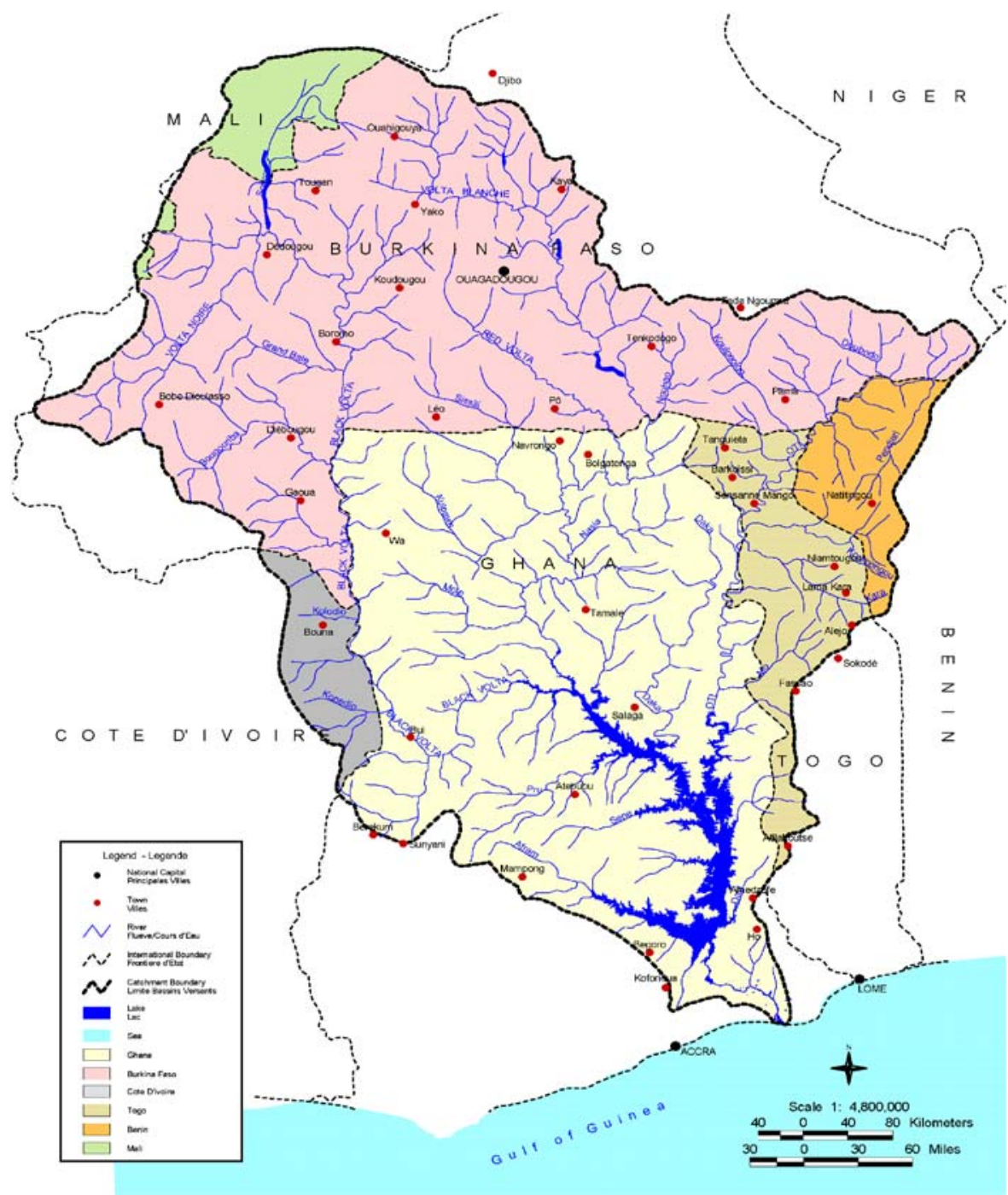

Fig. 1 The Volta Basin, showing political boundaries and important tributaries, source. Andah and Gichuki, 2003

The Volta encompasses at least four climatic zones, from lowland rainforest in the southern portions of the basin, where annual precipitation can exceed 2,000 mm, to Sahel-Sudan in the north, where average rainfall is well below $1,000 \mathrm{~mm}$ per year and potential evaporation is considerably higher. Basin-wide rainfall averages 1,025 mm per year (1936-1963), of which roughly $9 \%$ becomes river discharge, as measured by Akosombo Dam outflows. Climatic patterns are strongly influenced by the movement of the Inter-Tropical Convergence Zone (ITCZ), which generates unimodal as well as bimodal rainy seasons. In the South, there are two rainy seasons with peaks in June/July and September/October. The North has only 
one wet season, from May through November, with peak rainfall occurring in September. Annual rainfall exhibits extensive spatial and temporal variability, and unreliable precipitation patterns make rainfed agriculture a risky undertaking throughout much of the basin. Mean annual temperatures approach $30^{\circ} \mathrm{C}$ and humidity varies between $90 \%$ in coastal areas to below $20 \%$ in the North during the harmattan ${ }^{1}$ and the dry season. Estimates of annual potential open water evaporation range between $1350 \mathrm{~mm}$ in the South to $2000 \mathrm{~mm}$ in the Northern parts of the country (MoWH, 1998; van Edig et al., 2002).

Basin runoff exhibits higher temporal variability than the rainfall input due to nonlinear response and threshold effects, making the extent of utilizable water resources within the basin highly sensitive to variation in precipitation, and to alterations in land use and cover. Andreini et al. (2000) estimated an empirical annual rainfall-runoff relationship of the form:

$$
Q=0.529 \cdot(P-343) \quad\left(Q, P \text { in } \mathrm{km}^{3} / \text { year }\right)
$$

This implies that roughly half of precipitation volume becomes discharge, but only after $340 \mathrm{~km}^{3}$, or $85 \%$ of the average annual rainfall, is received. Mean basin yield was around $35 \mathrm{~km}^{3} /$ year prior to the closing of Akosombo Dam (1936-1963), and $31 \mathrm{~km}^{3} /$ year over the period 1967-1998. Time series analysis demonstrates that small changes in precipitation lead to proportionately larger changes in runoff, which is an issue of great concern given the likelihood of alteration in rainfall patterns as a consequence of changes in global circulation. Preliminary research by Kunstmann and Jung (2004) appears to identify numerous statistically significant climatic trends, notably decreasing precipitation and increasing temperature. GVP climatologists in Ghana and at IMK-IFU (Garmisch-Partenkirchen) are currently investigating probable changes (delays) in the date of onset of the rainy season over the last several decades, a phenomenon widely reported by farmers in the Basin (Laube, personal communication).

\subsection{Human geography}

The demographic, socioeconomic and health status of Volta Basin inhabitants can be summarized via selected indicators from the World Bank-World Development Indicators database (2004) and Human Development Report (2000), presented in Table 2. These aggregate statistics are national in scope, but should be representative of conditions within the basin in most cases, particularly for Ghana and Burkina Faso. By African standards, the basin is densely settled, with Ghana possessing roughly three times the mean population density of SubSaharan Africa (SSA). Per capita income in Volta Basin countries tends to be lower than the SSA average, although Ghana appears somewhat more prosperous when income is evaluated in Purchasing Power Parity (PPP) terms. Much of Ghana's affluence is located in urbanized regions to the south, however, outside basin boundaries. Foreign assistance is correspondingly greater than the regional average, particularly to Ghana and Burkina Faso. Life expectancy at birth is broadly consistent with SSA as a whole, which is to say well below potential. Among riparian residents, Ghanaians enjoy the longest lives, due in part to a low incidence of HIV/AIDS relative to the SSA region, although malaria persists as a serious problem. However, considerable progress has been made toward eradicating onchocerciasis

\footnotetext{
${ }^{1}$ The Harmattan, typically occurring in December - February, is characterized by hot, rainless conditions; and by the presence of atmospheric haze originating in the Sahara Desert. 


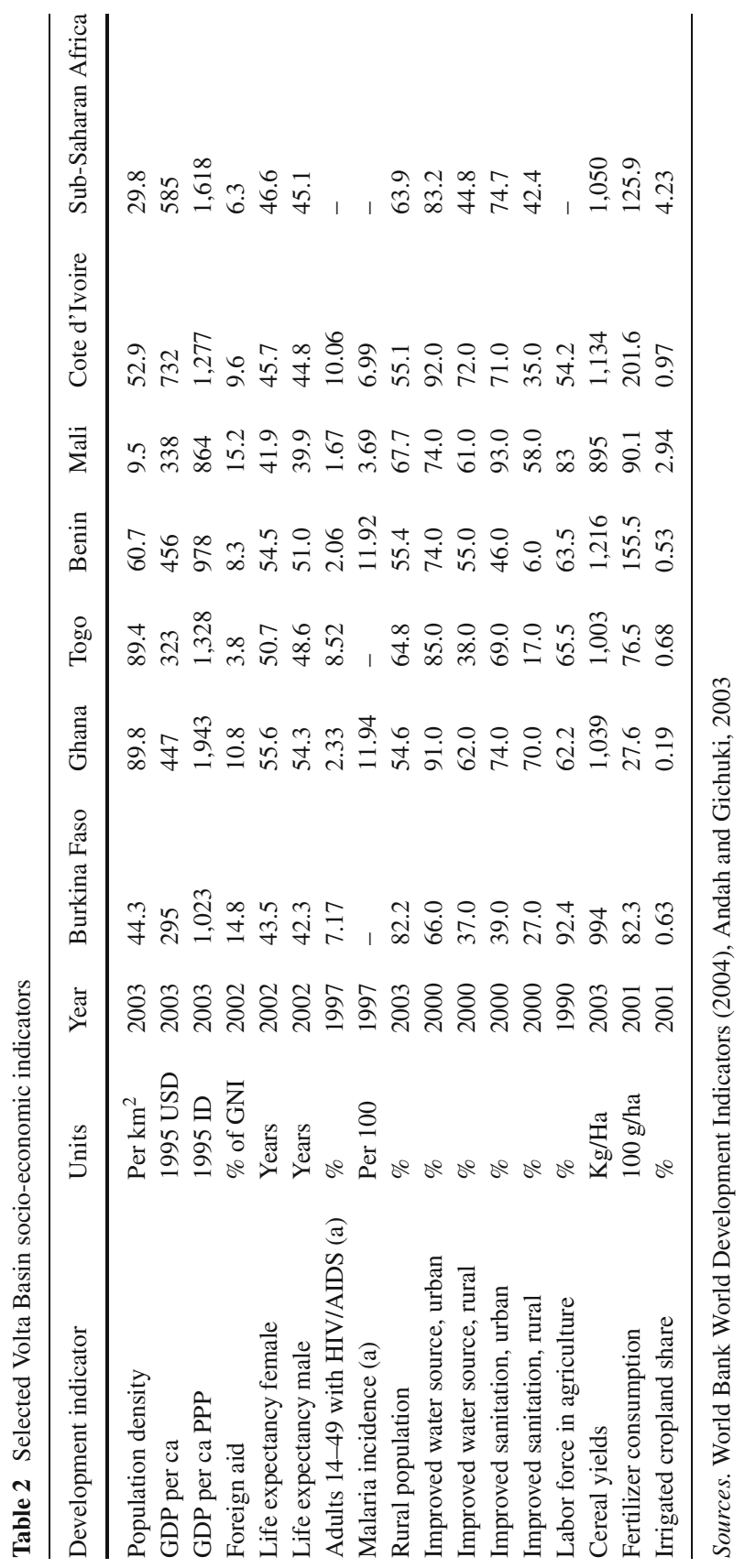


(river blindness), which was until recently endemic to the Northern regions of the basin (Andah and Gichuki, 2003).

Basin inhabitants are overwhelmingly rural, as throughout much of SSA. In Ghana, the percentage of Basin residents living in rural areas is greater than the national average suggests, since the densely settled southern and coastal areas, including Kumasi and Accra, lie outside basin boundaries. Rural residents in general are less likely to have access to improved water supply and sanitation, particularly in Burkina Faso. Roughly two in three Basin inhabitants, and nearly 9 out of 10 in Burkina Faso, are employed in agriculture. Agricultural productivity is low, at roughly 1 metric ton of cereal yield per hectare. Although this is consistent with agricultural performance throughout SSA, these yields are well below the world average of 2.2 MT per hectare, and compare even less favorably with East Asian yields, which average over 3.2 MT per hectare. Erratic and unreliable precipitation contributes significantly to the yield gap, although fertilizer consumption, at less than $3 \mathrm{~kg}$ per ha in Ghana, is only around $20 \%$ of SSA average $(12.6 \mathrm{Kg} / \mathrm{Ha})$ and far below the world average of nearly $100 \mathrm{Kg} / \mathrm{Ha}$. The factor of greatest significance from the perspective of water management is the extremely low percentage of cropland within the basin and surrounding areas that is currently under irrigation - less than 1\% in Ghana and Burkina Faso, as against $4.23 \%$ throughout SSA and $20 \%$ globally (WDI, 2004). Paradoxically, efforts to mitigate poverty and low agricultural productivity through irrigation investment will position the agricultural sector increasingly as a competitor to the power generation sector, arguably no less critical to overall economic development.

\subsection{The structure of demand and competition for water}

The downstream locations of Akosombo and Kpong dams, near the basin outlet, frame the primary conflict over Volta water resources: upstream consumptive use against downstream hydropower generation. The dam at Akosombo, originally proposed in the 1920's, was constructed by an international consortium in 1961 largely to provide (highly subsidized) hydropower to the Volta Aluminum Company (Valco) (Andreini et al., 2000). The availability of inexpensive hydropower was, and remains an important engine of economic growth for Ghana, critical to the viability of the mining and industrial sectors, and for surrounding countries which purchase Volta hydropower.

Ghana is but one of six riparian states sharing Volta waters, however. A significant proportion of Volta Lake inflow originates in the upstream countries of Burkina Faso and Togo. Efforts to develop water resources for hydropower production, irrigation and other purposes in these nations negatively impact storage in Volta Lake, although the impacts of climatic variability currently exceed the impacts of upstream abstraction. ${ }^{2}$ Two major storage reservoirs have already been built in Burkina Faso: Bagre (1.7 BCM live storage) on the White Volta and Kompienga (2.05 BCM) on the Oti (Obeng-Asiedu, 2004). Three additional dams are planned. If the proposed hydropower dam in Bui Gorge on the Black Volta is built (6 BCM), it may further complicate efforts to maintain storage in Volta Lake at optimal levels for hydropower production. The assertion that hydropower generation is a "non-consumptive" use of water means little when the point of generation lies downstream from competing, consumptive uses.

\footnotetext{
${ }^{2}$ For example, the low levels of Lake Volta in 1998 reflected low rainfall in the preceding rainy season (Van de Giesen et al., 2001).

Springer
} 
Table 3 Current and projected water demand

\begin{tabular}{|c|c|c|c|c|c|c|c|c|c|}
\hline \multirow[b]{2}{*}{ Country } & \multirow[b]{2}{*}{ Sector } & \multicolumn{5}{|c|}{ Millions cubic meters per year } & \multicolumn{3}{|c|}{ Change relative to $2000 \%$} \\
\hline & & 1990 & 2000 & 2010 & 2020 & 2025 & 2010 & 2020 & 2025 \\
\hline \multirow[t]{4}{*}{ Benin } & Domestic & - & 56 & 196 & 336 & 448 & 250 & 500 & 700 \\
\hline & Irrigation & - & 152 & 548 & 1,225 & 1,600 & 261 & 706 & 953 \\
\hline & Livestock & - & 40 & 94 & 133 & 175 & 135 & 233 & 338 \\
\hline & Total & - & 248 & 838 & 1,694 & 2,223 & 238 & 583 & 796 \\
\hline \multirow[t]{4}{*}{ Burkina Faso } & Domestic & 67 & 85 & 106 & 132 & 149 & 25 & 55 & 75 \\
\hline & Irrigation & 43 & 203 & 384 & 554 & 639 & 89 & 173 & 215 \\
\hline & Livestock & 37 & 46 & 61 & 78 & 88 & 33 & 70 & 91 \\
\hline & Total & 147 & 334 & 551 & 764 & 876 & 65 & 129 & 162 \\
\hline \multirow[t]{4}{*}{ Côte d'Ivoire } & Domestic & - & 4 & 5 & 12 & 14 & 25 & 200 & 250 \\
\hline & Irrigation & - & 19 & 57 & 166 & 276 & 200 & 774 & 1,353 \\
\hline & Livestock & - & 1 & 2 & 3 & 3 & 100 & 200 & 200 \\
\hline & Total & - & 24 & 64 & 181 & 293 & 167 & 654 & 1,121 \\
\hline \multirow[t]{4}{*}{ Ghana } & Domestic & 82 & 138 & 192 & 272 & 284 & 39 & 97 & 106 \\
\hline & Irrigation & 75 & 565 & 1,871 & 3,605 & 3,733 & 231 & 538 & 561 \\
\hline & Livestock & 18 & 26 & 41 & 63 & 67 & 58 & 142 & 158 \\
\hline & Total & 175 & 729 & 2,104 & 3,940 & 4,084 & 189 & 440 & 460 \\
\hline \multirow[t]{4}{*}{ Mali } & Domestic & 5 & 9 & 13 & 16 & 18 & 44 & 78 & 100 \\
\hline & Irrigation & 126 & 180 & 219 & 291 & 311 & 22 & 62 & 73 \\
\hline & Livestock & 4 & 34 & 74 & 123 & 142 & 118 & 262 & 318 \\
\hline & Total & 135 & 223 & 306 & 430 & 471 & 37 & 93 & 111 \\
\hline \multirow[t]{4}{*}{ Togo } & Domestic & 51 & 68 & 92 & 123 & 145 & 35 & 81 & 113 \\
\hline & Irrigation & 43 & 50 & 91 & 133 & 171 & 82 & 166 & 242 \\
\hline & Livestock & 15 & 19 & 22 & 30 & 36 & 16 & 58 & 89 \\
\hline & Total & 109 & 137 & 205 & 286 & 352 & 50 & 109 & 157 \\
\hline \multirow[t]{4}{*}{ Riparian states } & Domestic & - & 360 & 604 & 891 & 1,058 & 68 & 148 & 194 \\
\hline & Irrigation & - & 1,169 & 3,170 & 5,974 & 6,730 & 171 & 411 & 476 \\
\hline & Livestock & - & 166 & 294 & 430 & 511 & 77 & 159 & 208 \\
\hline & Total & - & 1,695 & 4,068 & 7,295 & 8,299 & 140 & 330 & 390 \\
\hline
\end{tabular}

Sources. MWH 1998, Andah and Gichuki, 2003; Laube and van de Giesen, 2005

Consumptive water use itself is anticipated to expand dramatically over the coming 20 years, driven primarily by population growth and expansion of surface irrigation (Table 3 ). There is at present little irrigated area within the basin - official estimates are roughly 8,000 out of a potential 1.2 million hectares in Ghana, and 20,000 out of a potential 165,000 Ha. in Burkina Faso (Obeng-Asiedu, 2004), although this figure almost certainly excludes much of the farmer-developed small scale irrigation. In Burkina Faso, actual irrigated area may be closer to 50,000 (van de Giesen, personal communication). Important irrigated crops within the basin include rice, which receives supplemental irrigation during the rainy season, and tomatoes, onions and maize during the dry season (MoFA). Much of the small scale irrigation is provided by small earthen dams which impound intermittent flow in small catchments in the North of Ghana and throughout Burkina Faso. These small reservoirs, while perhaps of appropriate scale for decentralized management, have high surface area to volume ratios, and thus may evaporate as much or more water than they make available for irrigation (Liebe, 2002). The number of such dams and associated irrigated commands is expanding rapidly, particularly in Burkina Faso. 
As Table 3 indicates, Ghanaian irrigation water consumptive demand is projected by MoWH (1998) to expand by a factor of six between 2000 and 2025; and in Burkina Faso, by a factor of three over the same period (Andah and Gichuki, 2003). Overall, domestic water supply (provided largely by wells in rural regions with water of suitable quality) is projected to increase from 360 to $1,058 \mathrm{MCM}$; livestock use from 166 to $511 \mathrm{MCM}$, and irrigation consumption from 1,169 to 6,730 MCM. Overall abstractive use will increase from roughly $1.7 \mathrm{~km}^{3}$ in 2000 to $8.3 \mathrm{~km}^{3}$ in 2025 , nearly all of which will be withdrawn at points upstream of the Akosombo hydropower generating facilities.

As growth in agricultural output and productivity, adequate domestic water supply and sanitation and power generation are all essential at this stage in the Basin region's economic development, the competition between consumptive uses and hydropower generation presents hard choices. Exacerbating this situation is the absence of an Inter-state Basin Compact, Authority or similar legal framework to regulate and allocate flows across international borders and to enable coordinated development of the Basin's water resources. Encouraging progress is being made toward such a governing structure, however, through the joint IUCN - Global Water Partnership project "Improving Water Governance in the Volta River Basin," commencing in 2004 (Odame-Ababio, 2004). Another development with the potential to alter the economic calculus underlying Volta water allocation is the recent approval by the World Bank of funding for the West African Gas Pipeline Project (World Bank, 2004). This US\$ 590 Million project will bring Nigerian natural gas to coastal locations in Benin, Togo and Ghana. Ex ante economic analysis (World Bank, 2002) suggests that electric power can be generated thermally using natural gas at 0.042 USD per KWH, as compared with 0.072 for hydropower. These and other evolving economic and political developments highlight the need for an integrated water resources DSS for the Volta Basin.

\section{Stakeholders and water management institutions}

As each of the riparian nations has a unique set of laws and institutions regarding the management of water resources, the following narrative will focus on Ghana, for which the GVP has the most complete information. Prior to the enactment of the 1992 Constitution, no single institution had authority over the water sector, although a (non-statutory) riparian doctrine was widely respected. Following the intent of Article 269 of the new Constitution, in 1996 the Ghanaian Parliament passed the Water Resource Commission Act (Act 522, 1996). This Act empowers the Water Resource Commission (WRC) to manage the nation's water resources, effectively acting on behalf of the President in whom all water rights are vested under a doctrine of public trust. Under the Act, no person or organization has the authority to divert, dam, store, abstract or use water, or to develop or maintain physical structures for the use of water resources apart from WRC's consent. The WRC was created in part to remedy the problems of unclear, conflicting or redundant mandates that characterized the sectoral approach to water resources management that prevailed prior to passage of Act 522 . Primary responsibilities of the new WRC, consistent with the philosophy of IWRM, include the following (Mensah (1999), in Laube and van de Giesen, 2005):

- to propose, co-ordinate and monitor plans and activities related to the development, improvement utilisation and conservation of water resources

- to grant water rights

- to collect, collate, store and disseminate data or information on water resources

- to require water user agencies to undertake research and experiments into water resources

空 Springer 
Table 4 Composition of the Ghanaian Water Resources Committee (WRC)

\begin{tabular}{ll}
\hline & Institution \\
\hline Water User Agencies & Volta River Authority (VRA) \\
& Ghana Water Company Limited (GWCL) \\
& Irrigation Development Authority (IDA) \\
& Forest Commission (FC) \\
& Minerals Commission (MC) \\
& Water Research Institute (WRI) \\
& Hydrological Services Department (HSD) \\
& Meteorological Services Division (MSD) \\
Research Organisations & Environmental Protection Agency (EPA) \\
& Independent Chairman \\
Regulatory Institution & Executive Secretary of the WRC \\
Others & Chief's Representative \\
& NGO's Representative \\
& Women's Representative \\
\hline
\end{tabular}

Source. Laube and van de Giesen, 2005

- to monitor and evaluate programmes for the operation and maintenance of water resources

- to advise the government on water resources

- to advise pollution control agencies on the management and control of the pollution of water resources

The WRC consists of an executive secretariat (currently an acting secretariat), and representatives of the primary agencies, institutions and scientific organisations involved in water resources management, as well as representatives of a range of stakeholder communities (Table 4). Although all agencies represented on the WRC have ceded some degree of power and autonomy over water resources decision-making, most seem content to voice their concerns and forward their agendas within the commission (van Edig et al., 2002b: 35-36).

The WRC has drafted a Water Policy, yet to be adopted by the Ghanaian Parliament, and a range of water use regulations and tariffs for the abstraction of raw water, approved in 2002. The WRC has also initiated two Basin Pilot Projects, in the Densu and White Volta Basins, where Integrated Water Resource Management (IWRM) strategies will be introduced and tested at the local level. Efforts to build awareness and solicit stakeholder participation in the two pilot basins have been made via public stakeholder forums at which the Basin Commission concept was introduced. Attempts have also been made to identify major water users, in order to bill their abstractions, in three out of the eight Ghanaian regions. Furthermore, a Water Resource Information System (WRIS) will be set up to collect, collate and disseminate relevant information and to fill existing data gaps. Concrete steps to establish international water sharing and management mechanisms within the Volta-Basin are also under way. (MoWH, 2002; Odame-Ababio, 2004).

Underlying statutory law and legislation, however, are longstanding regional traditions, practices and institutions regulating water use. Rivers, creeks, lakes, ponds and water holes are locally important sources of drinking, livestock and irrigation water in many rural areas, and in some deprived urban areas. Such waters are typically perceived as communal property, often held in trusteeship by chiefs or priests and priestesses. Chiefs and spiritual leaders effectively control these water resources, and enforce the local rules governing their use by threatening violators with spiritual or social sanctions. Sometimes these traditional authorities may act in co-operation with local administrative or political bodies. Enforcement of traditional rules sometimes proves to be difficult - traditional and spiritual leaders do not always abide by the trusteeship principle and may compromise the interests of those they represent for economic 
or political advantage. Furthermore, some of the traditional rules are losing influence as members of communities undergo Christianisation, or the secularizing effects of modernity.

Some traditional norms and values carry only ceremonial meaning whereas others, although spiritually anchored, have practical implications for resource allocation and use. For example, prohibitions on fishing during certain times of the year, or on livestock watering in the vicinity of fetching points, have important environmental, sanitary and distributional outcomes. One important traditional norm is the 'riparian doctrine'. Most Ghanaians believe that those who own land adjacent to or containing water bodies have the right to use this water as they see fit, but not the right to deny others access to the resource. This can even apply to privately dug wells, since in many Ghanaian societies it is morally unacceptable to deny others access to drinking water, and denial might in any case lead to severe conflicts. Although the 'riparian doctrine' and other traditional water rights are not recognized formally by the WRC, it rhetorically admits traditional knowledge and practice into the water resources management process. In general, however, because local institutions and norms regarding water resources vary considerably throughout the ethnically and culturally heterogeneous social landscape of Ghana, such traditions cannot be fully incorporated at the level of national or regional regulation, but may well influence local or district-level laws and practices. (Laube and van de Giesen, 2005).

Many of the most important actors in the Ghanaian water resources sector are not formally affiliated with the Government or WRC. Multilateral lending institutions (e.g., World Bank), international and faith-based NGOs (Water Aid, Catholic Relief Services, World Vision, ....) and bilateral assistance agencies (GTZ, KFW, CIDA, DANIDA, EU Development Fund) play important roles in the development of water resources at scales from basin to local, including the financing and construction of wells, small reservoirs, water supply and sanitation and irrigation systems in small towns and rural areas. Their actions are not in every case fully coordinated with Government water resources development policies, however (Laube, personal communication.)

\section{The GLOWA Volta Project: A decision support system for the Volta Basin}

The GLOWA Volta Project (http://www.glowa-volta.de), initiated in 2000, is one of five major scientific projects funded by the German Federal Ministry of Education and Research (BMBF) and designed to examine the problems of global climate change and water resources availability, management and use at the scale of major river basins. GLOWA research sites include the Danube and Elbe Basins in Western Europe, the Jordan in the Southern Mediterranean, and the Draa (Morocco), Oueme (Benin) and Volta River Basins in North and Western Africa. GLOWA projects aim to develop and to utilize a range of innovative instrumentation, simulation tools and system integration methods to enable the rational development, management and allocation of increasingly uncertain water resources in each setting (http://www.glowa.org).

Core scientific objectives of the GLOWA Volta Project (GVP) are the following:

1. Analysis of the physical and socioeconomic determinants of the hydrologic cycle in the face of projected global climate change, emphasizing (a) natural variability of precipitation, variations caused by human activities and their effect on the hydrologic cycle; (b) interactions between the hydrologic cycle, the biosphere and land use, (c) water availability and conflicting water uses, and (d) institutional and legal aspects of water resources management; and 
2. Development of a scientifically sound Decision Support System (DSS) for the assessment, sustainable use and development of water resources in the Volta Basin.

The GVP is an interdisciplinary research project, with respect both to the network of partner research organizations involved and to the structure of research clusters constituting the Project. The research network in the "North" includes the Center for Development Research (ZEF) at Bonn; the Institute for Climatic Research (IMK-IFU) at Garmisch-Partenkirchen, DLR (German Space Agency) at the University of Wurzburg, and the University of Wageningen, The Netherlands. Important research partners in the Volta Basin include the Water Research Institute (WRI), Savannah Agricultural Research Institute (SARI), Soil Research Institute (SRI) and the Institute of Statistical, Social and Economic Research (ISSER), respectively, in Ghana; and the Institut de l'Environment et de Recherches Agricoles (INERA) in Burkina Faso. Interdisciplinary research themes (clusters) include the following (ZEF, 2002):

- Atmosphere Cluster: Projects A1:Regional Climate Simulations and Evapotranspiration Tagging; A2: Hydro-Meteorological Monitoring System; and A3: Onset of the Rainy Season

- Land Use Cluster: Projects L1: Land Use Change and Detection; L2: Soil Characterization; L3: Vegetation Dynamics; L4: Modeling Spatial and Temporal Upscaling of Erosion and Hydrological Processes; and L5: Land Use Change Prediction Model (LUCC)

- Water Use Cluster: Projects W1: Runoff and Hydraulic Routing; W2: Water and Livelihood; W3: Institutional Analysis

- Technical Integration and Decision Support Cluster: Projects D1: Technical Integration of Socio-Economic and Environmental Modeling Subsystems; D2: Household Decisionmaking and Policy Response; D3: Experimental Application of Scientific Knowledge (Policy Pilot Study); and D4: Initiation of Policy Dialog at Basin Level.

The GVP was designed as a 9-year project, and is currently midway through Phase II of three planned phases. Phase I (2000-2003) consisted largely of establishing the GVP "infrastructure" - the network of biophysical instrumentation sites, the first rounds of socioeconomic surveys and fieldwork, and the establishment and calibration of working relationships with partner institutions within Ghana. The first cadre of 13 M.S. and Ph.D. students from Volta Basin countries completed their academic training and conducted scientific fieldwork in Phase I. During Phase II (2003-2006), research activities have expanded to Burkina Faso. Mesoscale climate modeling conducted at IMK-IFU is increasingly successful in simulating the West African climate, and short-term forecasts for the region are now available online (http://www.glowa-volta.de/atm/forecast.htm). Phase II research efforts are focused on the functional integration of mathematical simulation and modeling tools which will serve as the backbone of the Volta Basin Decision Support System (DSS). A prototype DSS is under development as a component of the WRC White Volta Pilot Project, and should be completed and tested within Phase II. During Phase III (2006-2009), the scope of the DSS will be expanded to encompass the entire Volta Basin, inclusive of transboundary flows, and the system will be transferred to research partners, including GVP-trained scientists, within the Basin.

Although GVP is a scientific project, the research agenda is ultimately guided by the requirements and interests of Basin stakeholders, broadly construed. GLOWA research in West Africa faces a number of exceptional challenges not typically encountered in the "North". Among the most important are the large scale and geographic heterogeneity of the Basin combined with scarcity of existing hydrologic, meteorological and land use data. Reliable 
socioeconomic data on Basin inhabitants, their livelihood activities, the nature and extent of their uses of water, and the water-related health risks they face are likewise limited in extent. In addition, the Volta is an international basin, encompassing portions of six West African countries and lacking effective transboundary water management protocols, thereby greatly expanding the requirements for institutional analysis. Finally, appropriate scientific expertise and supporting knowledge infrastructure are in relatively short supply within the region, although these skills and resources are essential for the successful implementation of integrated water resources management (IWRM) in the Basin. The following paragraphs describe the methodological approaches the GVP adopted to address these and other challenges. They will be seen to have several factors in common, including interdisciplinary structure, utilization of research networks, frequent consultation with basin stakeholders, and investment in scientific capacity building.

\subsection{Climatic observatory and bio-climatic research network for West Africa}

Volta Basin historical hydrologic and climatic data are in many areas inadequate for supporting informed water resources decision-making. The GVP strategy to address this data gap involves the assimilation of complementary data from direct measurement and remote sensing within state-of-the-art simulation models. High quality bio-climatic data is acquired through the establishment of a network of six heavily instrumented "super sites" arrayed along North-South (Ejura - Tamale - Navrongo - Boudtenga) and East-West (Kompienga - Boudtenga - Dano) transects in Ghana and Burkina Faso, respectively, and representative of each important climatic-ecological zone. At each site, water and energy budgets are calculated on the basis of direct measurements. In addition, nutrient fluxes, soil erosion and transport and other important biophysical phenomena are measured. GVP staff scientists work alongside and train Ph.D. candidates from Europe and Africa as well as locally recruited technicians, and site instrumentation is transferred to host country institutions over the course of the project. Through these activities, local technical capacity is enhanced in the process of generating the required project data.

A wide range of remotely sensed environmental data is acquired and interpreted by DLR (German Space Agency) scientists and GVP doctoral students, and by scientists at collaborating institutions including the Savannah Agricultural Research Institute (SARI) in Tamale, Ghana. Image classification is facilitated by the availability of ground truth collected at the "super sites," and at other GVP research locations throughout the basin. The integrated analysis of measured and remotely sensed data permits the identification of scaling rules characterizing the spatial behavior of important climatic, hydrologic and land cover variables. To date, Intsiful (2004) successfully developed upscaling laws for roughness length, surface albedo, surface emissivity, insolation factor and several other parameters using 1D and 3D SVAT models (LSM, MM5) linked to an advanced nonlinear parameter estimation tool (PEST). These data and rules provide the basis for calibration and validation of a suite of simulation models, including the mesoscale climate model MM5 (Grell et al., 1994), the physical hydrology model WaSIM (Schulla and Jasper 1998), and a prototype land conversion model, GV-LUDAS (Berger et al., 2004). These models are used in complementary modes, e.g., with MM5 generating boundary conditions for WaSIM, and both providing boundary conditions for land conversion simulations.

GLOWA Volta data acquisition activities are further augmented through the integration of GVP field research into a larger regional Biophysical Observation Network (BON) operated in conjunction with BIOTA West Africa (http://www.biota-w02.de), and INERA (Burkina Faso). The creation of a West African biophysical observation network not only increases Springer 
the spatial coverage and extent of data available to support water resources decision-making within the Basin, it also expands the effective resources of all participating institutes through the sharing of site maintenance costs. GVP and partners are currently negotiating to expand this network further through integration with the African Monsoon Multidisciplinary Analysis (AMMA) flux monitoring project, designed to make continuous observations on a selection of typical land covers under a broad range of climatic conditions over 2 years (Lloyd and Taylor, 2005).

\subsection{Socioeconomic research}

Socio-economic data on Volta Basin inhabitants, their economic activities and their water requirements and uses are also deficient, yet indispensable to the design of sound water management protocols. This is an area in which mathematical models are largely incapable of supplying otherwise missing data. To remedy this deficiency, GVP designed and is implementing structured household surveys in Ghana (2002, 2005) and Burkina Faso (2005). Six broad research issues are investigated: (1) access of households to safe water supply, (2) determinants of household water demand, (3) household expenditures on water, (4) water-related health indices, (5) factors motivating migration and (6) factors driving land use change. In order to integrate the socioeconomic surveys with parallel GVP investigations in the physical and natural sciences, a common sampling framework was developed. Reported data on water use, livelihood and health are linked to the physical environment in which respondents live, through geo-referencing of interview locations and coordinated sampling and testing of soil and water by trained technicians. Water quality samples are collected from the sources actually used by survey respondents, and soil samples collected from the plots they cultivate. This permits the cross-referencing and cross-validating of physical and socioeconomic data sets, and allows GVP scientists to evaluate the participants' actions, choices and responses in the objective context of their physical surroundings (Berger et al., 2002).

Additional insight is acquired through anthropological and sociological studies within the basin. These take place on two primary scales: local studies, in which GVP social scientists integrate themselves into community activities to observe firsthand and to participate in water-related activities. Through such case studies, GVP scientists have acquired a more precise picture regarding the structure of local authority with respect to land and water use decisions (Laube, 2004). At the national and regional levels, GVP researchers are identifying and evaluating the respective roles of institutions and actors within the Ghanaian water sector.

\subsection{A scientifically sound decision support system for Volta Basin stakeholders}

The primary objective of the GVP is the development of a scientifically sound Decision Support System (DSS) to assist decision-makers within the Volta region (a) in anticipating the potential consequences of global climate change as manifested within the Basin; (b) in identifying and, where appropriate, in implementing avoidance strategies to pre-empt such consequences; finally (c) in identifying and preparing to implement adaptation strategies, where avoidance strategies are unavailable or unlikely to succeed. The analysis must include endogenous trends within the basin, such as deforestation, nutrient depletion, population increase and migration, which interact with global trends to define the state of water resources.

It must be stressed that the DSS is not a "software and data" entity as such, although integrated mathematical simulation models linked to databases are central and indispensable components of the DSS. The decision support process involves the active participation of decision-makers and executive bodies, such as the WRC in Ghana, as well as those affected 


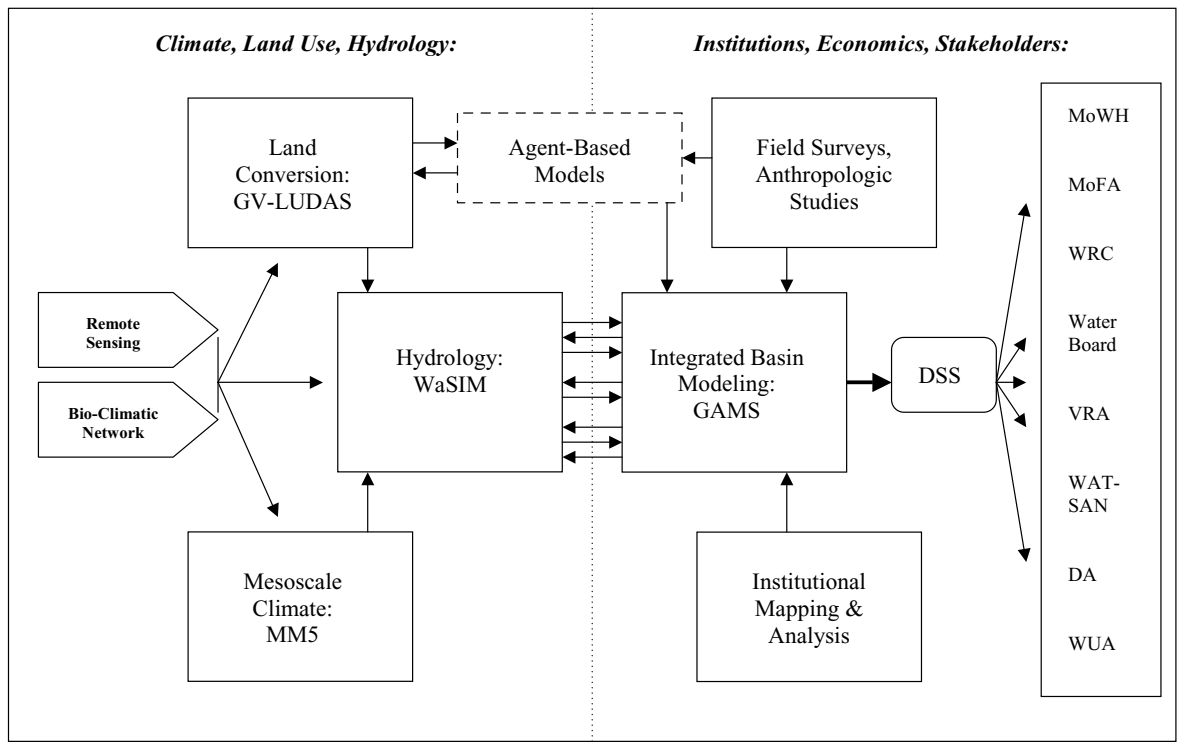

Fig. 2 Schematic representation of decision support system for the Volta Basin

by the decisions, which include such stakeholders as the VRA (hydropower generation), MoFA (irrigated agriculture), and the power consumers and farmers who make up their constituencies. Equally indispensable components of the DSS are mechanisms by which the views and interest of each stakeholder community are represented in the policy simulation process. An illustration will be provided with reference to the WRC/GVP White Volta Pilot Project.

The DSS is represented schematically in Figure 2, which is conceptually partitioned into physical and social science components. The physical science domain is indeed dominated by integrated simulation models: climate (MM5), land conversion (GV-LUDAS) and hydrology (WaSIM), linked via software applications currently under development in collaboration with the Department of Computer Science and Informatics, University of Bonn. Individual components can also serve as stand-alone decision support tools: MM5, for example, will provide short term- to seasonal forecasts which will assist farmers in determining safe planting dates.

The primary DSS integration task, however, involves combining output from physical simulation models with socioeconomic data and institutional rules and constraints in order to test the likely consequences of a set of policy decisions, such as investment strategies, in the face of simulated climate and land use changes. Fundamental to this integration is the interface between the linked atmosphere - land surface - flow system models and the social/policy domain. The policy simulation model under development for the Volta is the integration of a network flow hydrologic model with physical process simulation models of irrigated agricultural production, hydropower generation, municipal (domestic) and industrial demand; and with economic relationships characterized by the relative prices and values of water in its respective uses. The linked climate-hydrologic models provide boundary conditions, and institutional rules, including water rights and international water sharing protocols, provide constraints. The prototype Volta Basin model (Obeng-Asiedu, 2004) has evolved from the simulation-optimization model of the Aral Sea Basin, described in Cai et al. 
Table 5 GLOWA Volta Advanced Degrees completed or in progress, December 2004

\begin{tabular}{lllll}
\hline Research area & Europe & Ghana & Burkina Faso & Other Africa \\
\hline Climatology & 1 & 3 & & 4 \\
Hydrology, Water Engineering & 1 & 4 & 1 & 2 \\
Geography, Remote Sensing & 4 & 1 & 1 & \\
Agriculture, Forestry & 1 & 2 & 1 & 2 \\
Soils, other Natural Sciences & 1 & 2 & & \\
Mathematics, Computer Science & 1 & 1 & & \\
Economics, Ag. Economics & & 4 & & \\
Anthropology, Sociology & 4 & & 1 &
\end{tabular}

(2003) and subsequently developed for the Maipo Basin, Chile (Rosegrant et al., 2000), the Brantas Basin, Indonesia (Rodgers et al., 2003) and other locations. The integrated economichydrologic model is coded in GAMS (Brooke et al., 1998) and linked to large-scale non-linear optimization solvers (CONOPT, MINOS). An important component of the policy simulation process is the development of use cases, which begin with the research or policy question, for example the effectiveness of a particular type of adaptive intervention or investment, and then identify the simulation tools, institutional rules and assumptions and other required inputs, and the flow of data between model components that will be required to generate meaningful outputs. This process begins and ends with stakeholders, who provide the initial questions and rules, and who make use of the outputs.

\subsection{Scientific capacity building}

The most tangible measure of the GVP's progress to date is the number of scientific staff who have received advanced academic training and credentials through their participation in the project. Scientific capacity building is an explicit project goal, recognized from the outset as essential for success. Capacity building is, moreover, a bidirectional process. Students from the Volta Basin and surrounding countries receive advanced scientific training in Europe, but they also bring with them indispensable knowledge about the physical and human geography, politics and institutional settings of their home countries. This knowledge is particularly useful in the context of field research, which must be conducted in a manner sensitive to local custom and practice.

As of January 2004, 42 individuals have enrolled in GVP-supported graduate degree programs, the great majority in Doctoral programs (Table 5). To date, 13 have completed their degrees. Many have returned to affiliated institutions in Ghana, while others have been retained as postdoctoral scholars, continuing their research within the GVP. As Table 5 indicates, the distribution of graduate degrees reflects the interdisciplinary character of the project: the majority are awarded in natural science, but with significant numbers in the decision and social sciences as well.

\section{White Volta Pilot Project}

In 2000, the Ghanaian WRC conducted a Water Resources Management Problems Identification, Analysis and Prioritization Study in order to target specific river basins for intervention. In the White Volta Basin, encompassing much of northern and eastern Ghana, the WRC identified the following water sector problems, in order of priority: (a) flooding, (b) water 
shortage, (c) lack of comprehensive institutional and legal framework, and inadequate management information and data for water management, (d) high fluoride concentrations in groundwater, (e) water pollution and improper land use, and (f) high salinity of groundwater. In some cases, these problems were of national concern. The White Volta was selected as a pilot basin in which IWRM policies and practices could be tested and evaluated. An additional rationale for selecting the White Volta was that it is an international basin, shared with Burkina Faso, where some technical cooperation on water resources management had already been initiated (Amphoma, 2004).

The specific objectives of the White Volta pilot program are:

- To identify and motivate stakeholders for collaboration and participation in IWRM;

- To establish the institutional framework for IWRM;

- To develop a Water Action Plan; and

- To monitor and evaluate the IWRM process, all with a view toward wider application of the lessons learned in the White Volta setting.

The White Volta Pilot Project (WVPP) provides an illustration of the collaborative, decentralized and stakeholder-driven philosophy of the WRC and GVP. Initial WVPP activities included a stakeholder identification process, followed by a consultative stakeholder workshop held in November 2002; and the subsequent constitution of the Basin Board (Advisory Committee). The Board membership consists, inter alia, of riparian District Assemblies, research and data collection institutions, water and sanitation NGO's, religious bodies and traditional authorities (Amphoma, 2004). The WRC is currently staffing the WVPP office in Bolgatanga, shared by researchers from GVP and the CGIAR Challenge Program on Water and Food-funded Governance and Modeling project (G\&M). Wider co-operation will involve the IUCN, GWP and GEF through their transboundary Land and Water Management Program.

The structure of this collaborative project is summarized in Figure 3, defining the roles and responsibilities of the representatives of the WRC (Basin Officer), GVP (Scientific Coordinator) and G\&M (Postdoctoral Scientist). The WRC Basin Officer has overall managerial authority, serves as Basin Board Executive Secretary, and co-ordinates stakeholder activities. $\mathrm{He}$ is responsible for developing and implementing the Basin Action Plan, and for reviewing progress toward project objectives. Among his important responsibilities are registering of water use rights, collecting water fees, and generating public awareness of IWRM. He is also liaison with WRC headquarters. The primary task of the GVP Scientific Coordinator is to supervise and to participate in the development of the White Volta DSS. He provides scientific support to the Basin Officer by addressing WVPP data requirements, and by making the scientific process transparent to stakeholders. He will also be involved in scientific capacity building activities, and produce scientific documentation and scholarly publications. The Food and Water Challenge Program - Governance and Modeling Project is a collaboration between the International Food Policy Research Institute (IFPRI), ZEF, and partners in Ghana. The primary responsibility if the G\&M resident scientist is to interact with the community of stakeholders in order to develop an understanding of how water use decisions are made at household and community level. These processes will be modeled subsequently using agent-based techniques (Berger et al., 2004), and will in addition provide an important interface with the DSS.

Early evidence of effective engagement by stakeholders was observed at the White Volta Pilot Project Inception Workshop and Stakeholder Consultation held in Bolgatonga, Upper East Region in July 2005. Working groups focused on (1) Institutional Capacity Building for IWRM, (2) existing framework and history of collaboration in the White Volta Basin and (3) 


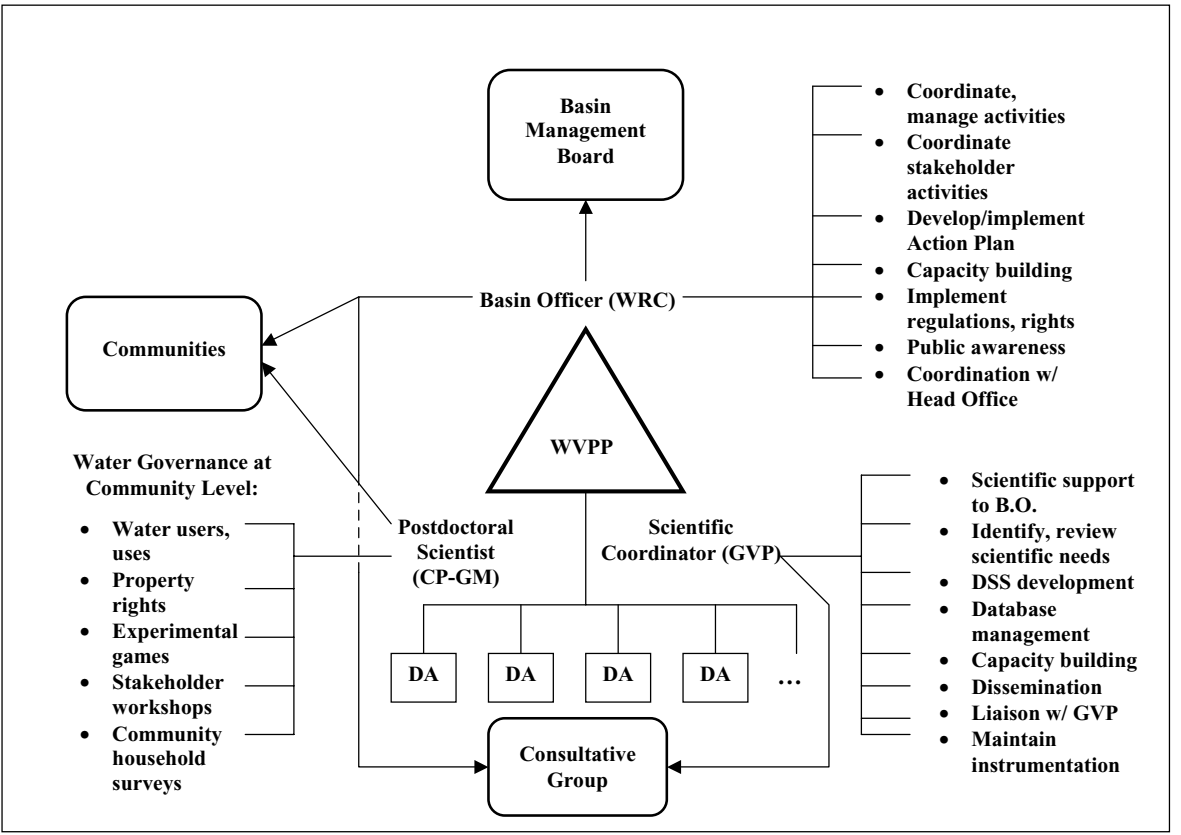

Fig. 3 Structure of White Volta Pilot Project

priority water management concerns within the sub-basin. Participants identified the need for an umbrella group representing stakeholders at all levels, the need for improved groundwater data collection, assessment and management and the need to establish research initiatives on flooding, water quality, waterbourne disease; and on water rights and the funding of water resources activities as high priorities within the basin (WRC, final communiqué July 15, 2005). The White Volta Pilot Project prototype DSS is scheduled for testing in 2006. The lessons learned will be incorporated into the Volta Basin DSS, which is the primary output of Phase III of the GLOWA Volta Project.

\section{Summary and conclusions}

The problems facing the water sector in the Volta Basin are, in most respects, generic to an increasing number of basins worldwide. These include increasing demand overlaid on static or possibly declining resources, increasing intersectoral competition, deteriorating water quality, weak, ineffective or conflicting rights and governance structures, and limited financial resources available for investment. The situation in the Volta Basin is distinguished largely as a matter of degree - the extremity of the Basin's vulnerability to the likely impacts of global climate change, the disproportionate dependency of Basin inhabitants on increasingly risky rainfed agriculture exacerbated by the exceptionally low levels of irrigation investment and irrigated area, the overall fragility of the West African economy and its sensitivity to movements in commodity prices, and the susceptibility of inhabitants to a wide range of waterborne and water-related illnesses. The list could be expanded.

Effective integrated management of water resources at the scale of large basins is difficult under the best of circumstances. Where scientific and financial resources and data are limited, 
the challenge is greater still. Viewed in this light, the GLOWA Volta Project is a highly ambitious undertaking. Evidence to date, however, suggests that the approach taken by the GVP, emphasizing coordinated interdisciplinary research bridging natural and social sciences, participation in regional research networks and emphasis on scientific capacity building, holds the potential to realize the project's primary objectives in the form of a scientifically sound Decision Support System capable of generating genuinely useful output. However, success in generating credible outputs from the White Volta Pilot Project will represent a critical milestone toward meeting these objectives.

\section{References}

Andah W, Gichuki F (2003) Volta basin profile: strategic research for enhancing agricultural water productivity (Draft). Accra: International Water Management Institute, Challenge Program on Water and Food

Amphoma B (2004) The enabling environment for Integrated Water Resources Management (IWRM) in the Volta Basin: the Case of the White Volta Basin. Workshop Paper, Promoting Bilateral Cooperation through Informed Dialog in the Volta Basin, Ho, June 8-10 2004

Andreini M, van de Giesen N, van Edig A, Fosu M, Andah W (March 2000) Volta Basin Water Balance. ZEF Discussion Papers on Development Policy No 21, Bonn

Berger T, Asante F, Osei-Akoto I (2002) GLOWA-Volta common sampling frame - selection of survey sites. Bonn, ZEF unpublished Research Documentation

Berger T, Park SJ, van de Giesen N, Vlek Paul LG (2004) Agent-based integration of disciplinary knowledge of resource use dynamics. J River Basin Manage, Special Issue on the GLOWA Volta Project. Forthcoming

Brooke A, Kendrick D, Meeraus A, Raman R (1998) GAMS: a user's guide. GAMS Development Corp, Washington, DC

Cai X, McKinney DC, Lasdon L (2003) An integrated hydrologic-agronomic-economic model for River Basin management. J Water Resour Plann Manage 121(9):4-17

Center for Development Research (ZEF) (2002) GLOWA Volta phase II - From concepts to application. Center for Development Research (ZEF), Bonn

Grell G, Dudhia J, Stauffer D (1994) A description of the fifth-generation penn state/ncar meso-scale model (MM5). NCAR Technical Note, NCAR/TN-398+STR

Intsiful J (2004) Upscaling of land surface parameters through inverse-svat modeling. Ecology and Development Series No 20. Center for Development Research, Bonn

Kunstmann H, Jung G (2004) Impact of regional climate change on water availability in the Volta Basin of West Africa. Submitted to IAHS, October 2004

Laube W, van de Giesen N (2005) Ghanaian water law and policy: institutional and hydrological perspectives. In: Wallace JS, Wouters P, Pazvakavambwa S (eds) hydrological information in water law and policy: current practices and future potential. Kluwar, Forthcoming

Laube W (2004) Promise and perils of water reform: perspectives from Northern Ghana. Journal of River Basin management, special issue on the GLOWA Volta Project. Forthcoming

Liebe J (2002) Estimation of water storage capacity and evaporation losses of small reservoirs in the upper East Region of Ghana. Diploma Thesis, Geographische Institute der Rheinischen Friedrich-WilhalmsUniversitat, Bonn

Lloyd C, Taylor C (2005) AMMA task team 2 reference document

Mensah KB (1999) Water law, water rights and water supply (Africa). Ghana - study country report. Silsoe, Department for International Development: 28

Ministry of Works and Housing (MoWH) (1998) Ghana's water resources: management challenges and opportunities. Accra, Ministry of Works and Housing

Ministry of Works and Housing (MoWH) (2002) Background Paper on Water resources management and ghana poverty reduction strategy. Final Report. Accra, Ministry of Works and Housing:70

Obeng-Asiedu P (2004) Allocating water resources for agricultural and economic development in the Volta Basin. European University Studies, Series V, Economics and Management, Vol 3096

Odame-Ababio K (2004) Water politics in the Volta Basin - defusing conflict, risks. Workshop Paper, Promoting Bilateral Cooperation through Informed Dialog in the Volta Basin. Ho, June 8-10 2004

Rodgers C, Siregar M, Wahida Sumaryanto, Hendradja B, Suprapto S, Zaafrano R (2001) Integrated economichydrologic modeling of the Brantas Basin, East Java, Indonesia: issues and challenges. In: integrated water resources management in a river basin context: institutional strategies for improving agricultural water 
management, Proceedings of an International Workshop held in Malang, Indonesia January 15-19, 2001. International Water Management Institute, Colombo, Sri Lanka

Rosegrant M, Ringler C, McKinney DC, Cai X, Keller A, Donoso G (2000) Integrated economic-hydrologic water modeling at the Basin Scale: The Maipo River Basin. J Agric Econ (IAEA) 24(1):33-46

Schulla J, Jasper K (1998) Model description WASIM-ETH (Water Balance Simulation Model ETH). ETHZurich, Zurich

Sutherland JW, Ben S, Kwame A, Osafu-Kissi A (2004) Innovative approaches to sustainable hydro power production in the volta basin-The VRA Initiative. Workshop Paper, Promoting Bilateral Cooperation through Informed Dialog in the Volta Basin, Ho, June 8-10 2004

Van de Giesen M, Andreini N, van Edig A, Vlek P (2001) Competition for Water Resources of the Volta Basin. In: Regional Management of Water Resources (Proceedings of a symposium held during the sixth IAHS Scientific Assembly at Maastricht, The Netherlands, July 2001.) IAHS Publication no. 268, 2001

van Edig A, Laube W, van de Giesen N (2002) Internationale und nationale Wasserkonflikte: Institutionelle und rechtliche Hintergründe der Wassernutzung des Volta-Flusses am Beispiel Ghanas. Wasserkonflikte in der Dritten Welt. G. M. et. al. Mainz, Johannes Gutenberg-Universität Mainz 15:75-94

van Edig A, Engel S, Laube W (2002) Ghana's Water Institutions in The Process of Reform. Reforming Institutions for Sustainable Water Management. SN Bonn et al., German Development Institute

World Bank, MIGA (2004) Project Appraisal Document on A Proposed IDA Partial Risk Guarantee in the Amount of US\$ 50 Million for Ghana and a Proposed MIGA Guarantee in the Amount of US\$ 75 Million for Sponsors' Equity to the West African Gas Pipeline Company Limited for the West African Gas Pipeline Project. Report No 30335-AFR

World Bank (November 11, 2004) Updated Project Information Document (PID). Africa - 3A - West African Gas Pipeline (IDA S/UP). Report No.: AB493

World Bank (2004) World Development Indicators on-line database (http://publications.worldbank. org/WDI/) 